\title{
Controlling the Incidence of Fusarium oxysporum f.sp. lycopersici in Tomato by Application of the Newly Formulated Botanical Fungicide (Polymin 40 EC)
}

\author{
R. Parimala Devi* and P. Marimuthu \\ Department of Agricultural Microbiology, Tamil Nadu Agricultural University, \\ Coimbatore - 641 003, India \\ *Corresponding author
}

\section{A B S T R A C T}

\section{Keywords}

Botanical fungicide,

Fusarium

oxysporum f.sp.

lycopersici,

Polymin,

Polygonum minus

Article Info

Accepted:

28 April 2018

Available Online:

10 July 2018
The chloroform extract of Polygonum minus Huds. was found to exhibit inhibitory effect against Fusarium oxysporum f.sp. lycopersici under laboratory conditions. Hence a new botanical fungicide (Polymin $40 \mathrm{EC}$ ) was formulated from the chloroform extract of Polygonum minus Huds. Polymin $40 \mathrm{EC}$ to control the pathogen under in vivo conditions. Various concentrations of Polymin $40 \mathrm{EC}$ were evaluated for their performance on seed infection, germination and vigour of tomato and it was found that Polymin $40 \mathrm{EC}$ at $2 \%$ concentration increased the germination and vigour with the significant reduction in seed infection. Application of Polymin 40 EC increased the activity of plant defense enzymes such as peroxidase (PO), polyphenol oxidase (PPO), phenylalanine ammonia lyase (PAL) and phenol content of tomato plant. Application of two percent Polymin $40 \mathrm{EC}$ was found to be effective in controlling the incidence of Fusarium oxysporum f.sp. lycopersici in tomato plant.

\section{Introduction}

Plants have provided man with all his needs in terms of shelter, clothing, food, flavours, fragrances and not the least, medicines. Much of the wealth of a country resides in its plant inheritance, whether the plants are endemic, naturalized or recent introduction (Mitchell and Ahmad, 2005). India has an extensive area of forest enriched with plant diversity. In agriculture, the crop loss due to plant pathogens has become a major concern. nowadays. Increased usage of different chemical based products to control these pathogens have resulted in problems like residual effect of chemicals in agri-based products, increased resistance for chemicals in target pathogens and environmental pollution. Crude extracts of some well known medicinal plants are used to control some of the plant pathogens. Use of botanicals in plant disease management assumes special significance by 
being an ecofriendly and cost effective strategy, which can be used in integration with other strategies for a greater levels of protection with sustained crop yields. With this background, the present research is formulated to explore the antimicrobial activity of Polygonum minus against Fusarium oxysporum fsp. Lycopersici.

\section{Materials and Methods}

\section{Disease incidence (Blotter method)}

The tomato seeds (PKM1) showing natural infections were used to find out the efficacy of various concentrations $(0.50,1.0,1.5$ and $2.0 \%$ ) of botanical formulation of $P$. minus (Polymin 40EC). The seeds (100 seeds) were soaked in each treatment with botanical formulation of $P$. minus (Polymin 40EC) for 2 $\mathrm{h}$ and replicated four times. A control was maintained by soaking the seeds in distilled water. Twenty five seeds of each treatment were placed on moist blotters (ISTA, 1993) in petriplate and incubated $\left(20 \pm 2^{\circ} \mathrm{C}\right)$ for $12 \mathrm{~h}$ of alternate natural UV light and $12 \mathrm{~h}$ darkness. The seeds were examined for growth of seed borne pathogens on eighth day of treatment. The seed infection was expressed in percentage.

The treatments include:

$\mathrm{T}_{1}-0.50 \%$ botanical formulation of $P$. minus (Polymin 40EC)

$\mathrm{T}_{2^{-}} 1.0 \%$ botanical formulation of $P$. minus (Polymin 40EC)

$\mathrm{T}_{3^{-}} 1.5 \%$ botanical formulation of $P$. minus (Polymin 40EC)

$\mathrm{T}_{4-}-2.0 \%$ botanical formulation of $P$. minus (Polymin 40EC)

$\mathrm{T}_{5}$ - Mancozeb (0.2\%)
$\mathrm{T}_{6}$ - Biocontrol agent (T. viride)

$\mathrm{T}_{7-}$ Uninoculated control

\section{Germination (\%)}

The tomato seeds (PKM1) seeds were soaked in botanical formulation of $P$. minus (Polymin 40EC) for $18 \mathrm{~h}$ and then dried under shade. Four replicates of 100 seeds were uniformly placed on standard germination paper rolltowel medium (ROLL towel medium, ISTA, 1993) and kept in germination room maintained at $25 \pm 2^{\circ} \mathrm{C}$ and $90 \pm 2$ per cent relative humidity. After the test period of 14 days, the seedlings were evaluated as total number of normal seedlings and germination as percentage. Similarly different concentration of $P$. minus (Polymin 40EC) was used for evaluating the per cent germination.

\section{Root length (cm)}

On fourteenth day, ten normal seedlings per replication from roll towel medium were carefully removed at random from each treatment and the root length was measured from the base to the top of the primary root and the mean value was calculated and expressed in $\mathrm{cm}$.

\section{Shoot length $(\mathrm{cm})$}

Ten normal seedlings from roll towel medium were carefully removed at random from each treatment and the shoot length was measured from the base of the shoot to tip of primary leaf on the fourteenth day and the mean value was expressed in $\mathrm{cm}$.

\section{Vigour index (VI)}

The Vigour Index (VI) was compared (AbdulBaki and Anderson, 1973) adopting the following formula and expressed as whole number. 
$\mathrm{VI}=$ Germination $(\%) \times$ Mean total length of seedling in $\mathrm{cm}$ (mean length of shoot and root).

Evaluation of the effect of Polymin 40EC on $F$. oxysporum f.sp. lycopersici under pot culture conditions

Different concentrations of Polymin 40EC $(0.50,1.0,1.5$ and $2.0 \%)$ were prepared to test the efficacy on different fungal pathogens under glass house conditions. Percent disease index and percent disease incidence was calculated from the observations recorded under pot culture condition.

The treatments include:

$\mathrm{T}_{1}-0.50 \%$ botanical formulation of $P$. minus (Polymin 40EC)

$\mathrm{T}_{2^{-}}-1.0 \%$ botanical formulation of $P$. minus (Polymin 40EC)

$\mathrm{T}_{3^{-}} 1.5 \%$ botanical formulation of $P$. minus (Polymin 40EC)

$\mathrm{T}_{4}-2.0 \%$ botanical formulation of P.minus (Polymin 40EC)

$\mathrm{T}_{5}$ - Mancozeb (0.2\%)

$\mathrm{T}_{6}$ - Biocontrol agent (T. viride)

$\mathrm{T}_{7^{-}}$Uninoculated control

$\mathrm{T}_{8^{-}}$Inoculated control

Method of inoculation of $F$. oxysporum f.sp. lycopersici

Forty five days old plants of tomato (PKM1) were inoculated with spores $F$. oxysporum f.sp. lycopersici at a concentration of $7 \times 10^{6}$ spore $/ \mathrm{ml}$. After $24 \mathrm{~h}$, the plants were sprayed with different concentration of Polymin 40EC
$(0.50,1.0,1.5$, and $2.0 \%)$. Second and third spraying was taken up in 15 days interval.

Biochemical changes induced by plant extracts in crop plants

Tomato (PKM1) plants were inoculated with Polymin 40EC at the concentration of 0.50 , 1.0, 1.5 and 2.0 per cent. Control plants were sprayed with distilled water. Three replicates of each treatment were maintained. The sprayed plants were inoculated with the pathogen $48 \mathrm{~h}$ after spraying and the plant samples were collected at specific time intervals viz., 0, 48, 96, 144 and $240 \mathrm{~h}$ after inoculation, for studying the induced changes.

\section{Assay of peroxidase (Puttur, 1974)}

The reaction mixture consisted $1.5 \mathrm{ml}$ of 0.05 $\mathrm{M}$ pyrogallol, $0.5 \mathrm{ml}$ of enzyme extract and $0.5 \mathrm{ml} 1$ per cent $\mathrm{H}_{2} \mathrm{O}_{2}$. The changes in absorbance at $420 \mathrm{~nm}$ were recorded at 30 seconds interval for $3 \mathrm{~min}$. The enzyme activity was expressed as changes in the absorbance per min per $\mathrm{g}$ of sample.

Assay of polyphenoloxidase (Mayer et al., 1965)

The reaction mixture consisted of $200 \mu \mathrm{l}$ of enzyme extract and $1.5 \mathrm{ml}$ of $0.1 \mathrm{M}$ sodium phosphate buffer. To start the reaction, $200 \mu \mathrm{l}$ of $0.01 \mathrm{M}$ catechol was added and the activity was expressed as changes in absorbance at $495 \mathrm{~nm}$ per min per $\mathrm{g}$ of sample.

\section{Estimation of total phenol (Spies, 1955)}

A sample quantity of $0.1 \mathrm{ml}$ was added to 2.8 $\mathrm{ml}$ of water and $0.25 \mathrm{ml}$ of Folin Ciocalteau reagent and the solution was kept at $25^{\circ} \mathrm{C}$. After $3 \mathrm{~min}, 1 \mathrm{ml}$ of 20 per cent sodium carbonate was added. The absorbance of developed blue colour was measured using spectrophotometer at $650 \mathrm{~nm}$. Catechol was 
used as the standard. The amount of phenolics was expressed as $\mu \mathrm{g}$ catechol per $\mathrm{g}$ of sample.

\section{Assay of phenyl ammonia lyase (Zucker,} 1965)

The reaction mixture containing $0.4 \mathrm{ml}$ of enzyme extract was incubated with $0.5 \mathrm{ml}$ of $0.1 \mathrm{M}$ borate buffer and $0.5 \mathrm{ml}$ of $12 \mathrm{mM} \mathrm{L}$ phenylalanine in the same buffer for $30 \mathrm{~min}$ at $30^{\circ} \mathrm{C}$. The amount of trans-cinnamic acid formed was calculated using its extinction coefficient of 9630 M-1. Enzyme activity was expressed as nmol trans cinnamic acid per min per $g$ of sample.

\section{Results and Discussion}

Tomato seeds treated with 2.0 per cent Polymin $40 \mathrm{EC}\left(\mathrm{T}_{4}\right)$ recorded 99.34 per cent reduced seed infection by $F$. oxysporum f.sp. lycopersici than the untreated control (Table 1). The treatments $T_{1}(0.50$ per cent Polymin 40EC), $\mathrm{T}_{2}$ (1.0 per cent Polymin 40EC), $\mathrm{T}_{3}$ (1.5 per cent Polymin 40EC), $\mathrm{T}_{5}$ (Mancozeb $0.2 \%)$ and $\mathrm{T}_{6}(T$. viride) recorded 88.58, $90.76,96.73,91.30$ and 91.84 per cent reduced seed infection over the control respectively.

The germination of tomato seedlings was 92.50 per cent in $\mathrm{T}_{4}(2.0 \%$ per cent Polymin 40EC) which was 11.98 per cent increase over the control.

Vigour of tomato seedlings was increased by 75.28 per cent over the control in $\mathrm{T}_{4}(2.0 \%$ Polymin 40EC) (Table 2). The maximum shoot (12.82) and root length (9.50) was observed in $\mathrm{T}_{4}(2.0 \%$ Polymin 40EC) followed by 12.40 and $9.48 \mathrm{~cm}$ in $\mathrm{T}_{3}$ (1.5\% Polymin 40EC), 11.08 and $9.47 \mathrm{~cm}$ in $\mathrm{T}_{2}(1.0 \%$ Polymin 40EC). Enzyme activities like PO, PPO, PAL and phenol content were constantly measured in tomato plants on 0, 2, 4, 6 and 10 days after challenge inoculation with $F$. oxysporum f.sp. lycopersici. The maximum PO activity was recorded in 2 per cent Polymin 40EC treated tomato plants (3.943 OD $\mathrm{min} / \mathrm{g}$ ) on 6 days after challenge inoculation (Fig. 1). The untreated control recorded 1.612 OD min/g of PO activity on 6 days after challenge inoculation and this was lower than all other treatments.

Maximum PPO activity was observed in $\mathrm{T}_{4}$ (2.0\% Polymin 40EC) on 4 days after inoculation (Fig. 1). The PPO activity was lower in inoculated control (1.310 OD min/g) when compared to plants treated with various concentrations of Polymin 40EC, Mancozeb $(0.2 \%)$ and $T$. viride on fourth day after challenge inoculation. The PAL activity was maximum in 2.0 per cent Polymin 40EC treated plants $(8.985 \mathrm{OD} \mathrm{min} / \mathrm{g})$ on 6 days after inoculation than healthy and inoculated control (Fig. 1).

In all the treatments, maximum phenol content reached on sixth day after inoculation. The phenol content was significantly higher in $\mathrm{T}_{4}$ (2.0\% Polymin 40EC - 555.06 $\mu \mathrm{g}$ of catechol /g) than the control (Fig. 1). The Mancozeb $(0.2 \%)$ and $T$. viride treated plants recorded the phenol content of $426.56 \mu \mathrm{g}$ of catechol $/ \mathrm{g}$ and $422.00 \mu \mathrm{g}$ of catechol $/ \mathrm{g}$ on 6 days after challenge inoculation.

The botanical formulation at 2 per cent was found to reduce the seed infection by $F$. oxysporum f.sp. lycopersici and also increased the vigour of tomato $(75.28 \%)$. The beneficial effect of botanical formulations in inhibiting the fungal pathogens and increasing the seedling vigour has been reported in several studies. Dongzhi (2004) have reported that the medicinal plants like Aloe vera contained natural plant growth regulators and it promoted shoot and root length of turnips.

Induction of defense proteins makes the plant resistant to pathogen invasion. 
Table.1 Effect of botanical formulation of $P$. minus (Polymin 40EC) on seed infection and seed germination of tomato $-F$. oxysporum f.sp. lycopersici

\begin{tabular}{|c|c|c|c|c|}
\hline \multirow[t]{2}{*}{ Treatment } & \multicolumn{2}{|c|}{ Seed infection } & \multicolumn{2}{|c|}{ Seed germination } \\
\hline & $\begin{array}{c}\text { Infection } \\
(\%)^{*}\end{array}$ & $\begin{array}{c}\text { Reduction } \\
\text { over control }\end{array}$ & $\begin{array}{c}\text { Germination } \\
(\%)^{*}\end{array}$ & $\begin{array}{c}\text { Increase } \\
\text { over control }\end{array}$ \\
\hline $\begin{array}{l}\mathrm{T}_{1}(0.50 \% \text { Polymin } \\
\text { 40EC })\end{array}$ & 10.50 & 88.58 & 86.50 & 4.70 \\
\hline $\begin{array}{l}\mathrm{T}_{2}(1.00 \% \text { Polymin } \\
\text { 40EC) }\end{array}$ & 8.50 & 90.76 & 88.90 & 6.30 \\
\hline $\begin{array}{l}T_{3}(1.50 \% \text { Polymin } \\
\text { 40EC })\end{array}$ & 3.00 & 96.73 & 90.60 & 9.68 \\
\hline $\begin{array}{l}\mathrm{T}_{4}(2.00 \% \text { Polymin } \\
\text { 40EC })\end{array}$ & 0.60 & 99.34 & 92.50 & 11.98 \\
\hline $\mathrm{T}_{5}($ Mancozeb $0.2 \%)$ & 8.00 & 91.30 & 85.00 & 2.90 \\
\hline $\mathrm{T}_{6}(T$. viride $)$ & 7.50 & 91.84 & 84.90 & 2.78 \\
\hline $\mathbf{T}_{7}$ (Control) & 92.00 & & 82.60 & \\
\hline
\end{tabular}

*Mean of four replications (5 plants/replication)

Table.2 Effect of botanical formulation of P. minus (Polymin 40EC) on vigour of tomato seedlings $-F$. oxysporum f.sp. lycopersici

\begin{tabular}{|l|c|c|c|c|c|c|}
\hline \multicolumn{1}{|c|}{ Treatment } & $\begin{array}{c}\text { Shoot } \\
\text { length } \\
\text { (cm)* }\end{array}$ & $\begin{array}{c}\text { Increase } \\
\text { over } \\
\text { control }\end{array}$ & $\begin{array}{c}\text { Root } \\
\text { length } \\
\text { (cm)* }\end{array}$ & $\begin{array}{c}\text { Increase } \\
\text { over } \\
\text { control }\end{array}$ & $\begin{array}{c}\text { Vigour } \\
\text { index } \\
\text { (VI)* }\end{array}$ & $\begin{array}{c}\text { Increase } \\
\text { over } \\
\text { control }\end{array}$ \\
\hline $\mathbf{T}_{\mathbf{1}}(\mathbf{0 . 5 0 \%}$ Polymin 40EC) & 10.39 & 44.10 & 8.93 & 26.67 & 835.59 & $\mathbf{4 1 . 8 8}$ \\
\hline $\mathbf{T}_{\mathbf{2}}(\mathbf{1 . 0 0 \%}$ Polymin 40EC) & 11.08 & 53.67 & 9.47 & 34.33 & 913.45 & $\mathbf{5 5 . 1 0}$ \\
\hline $\mathbf{T}_{\mathbf{3}}(\mathbf{1 . 5 0 \%}$ Polymin 40EC) & 12.40 & 71.98 & 9.48 & 34.47 & 991.16 & $\mathbf{6 8 . 3 0}$ \\
\hline $\mathbf{T}_{\mathbf{4}}(\mathbf{2 . 0 0 \%}$ Polymin 40EC) & 12.82 & 77.80 & 9.50 & 34.75 & 1032.30 & $\mathbf{7 5 . 2 8}$ \\
\hline $\mathbf{T}_{\mathbf{5}}(\mathbf{M a n c o z e b} \mathbf{0 . 2 \%})$ & 7.59 & 5.27 & 7.13 & 1.13 & 625.60 & $\mathbf{6 . 2 2}$ \\
\hline $\mathbf{T}_{\mathbf{6}}(\mathbf{T}$. viride) & 7.63 & 5.83 & 7.18 & 1.84 & 628.68 & $\mathbf{6 . 7 4}$ \\
\hline $\mathbf{T}_{\mathbf{7}}$ (Control) & $\mathbf{7 . 2 1}$ & & $\mathbf{7 . 0 5}$ & & $\mathbf{5 8 8 . 9 4}$ & \\
\hline
\end{tabular}

*Mean of four replications (5 plants/replication) 
Fig.1 Changes in enzyme activity and phenol content by application of Polymin 40EC in tomato challenged with $F$. oxysporum f.sp. lycopersici
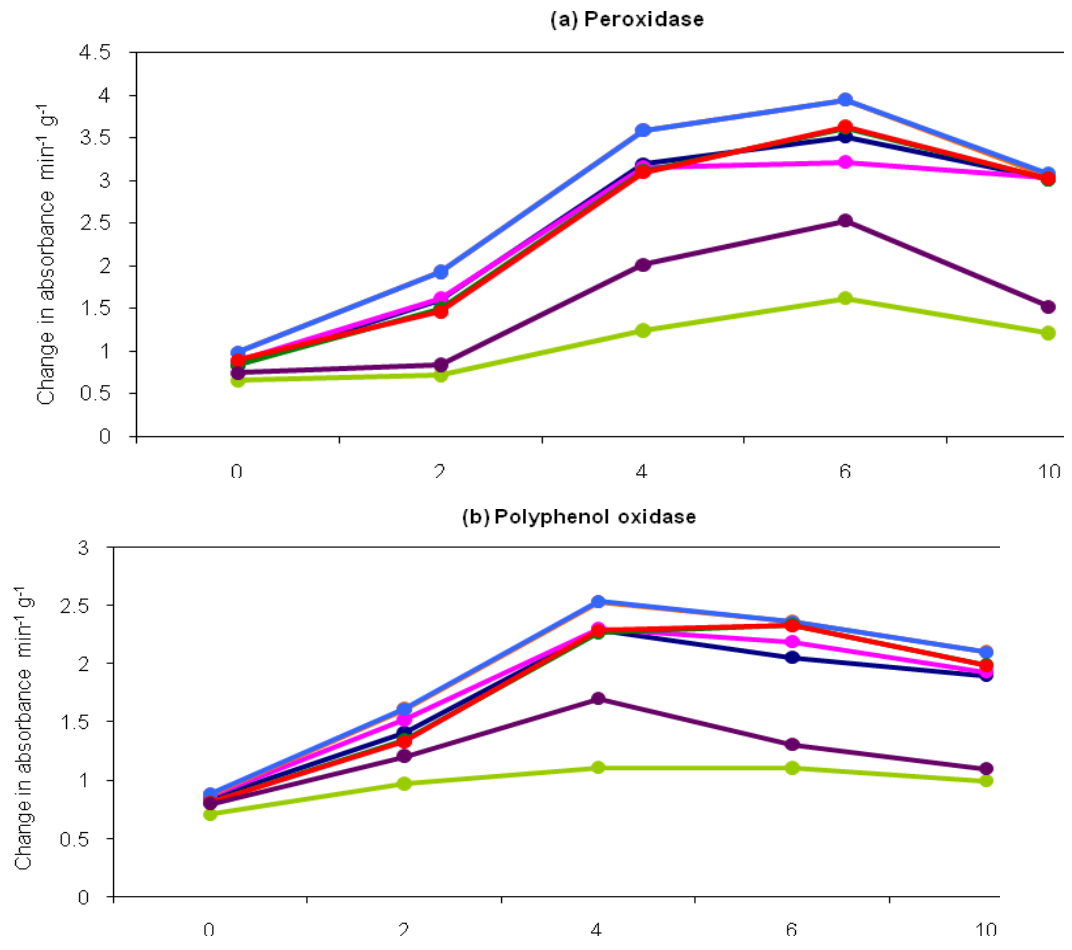

(c) Phenylalanine ammonia lyase
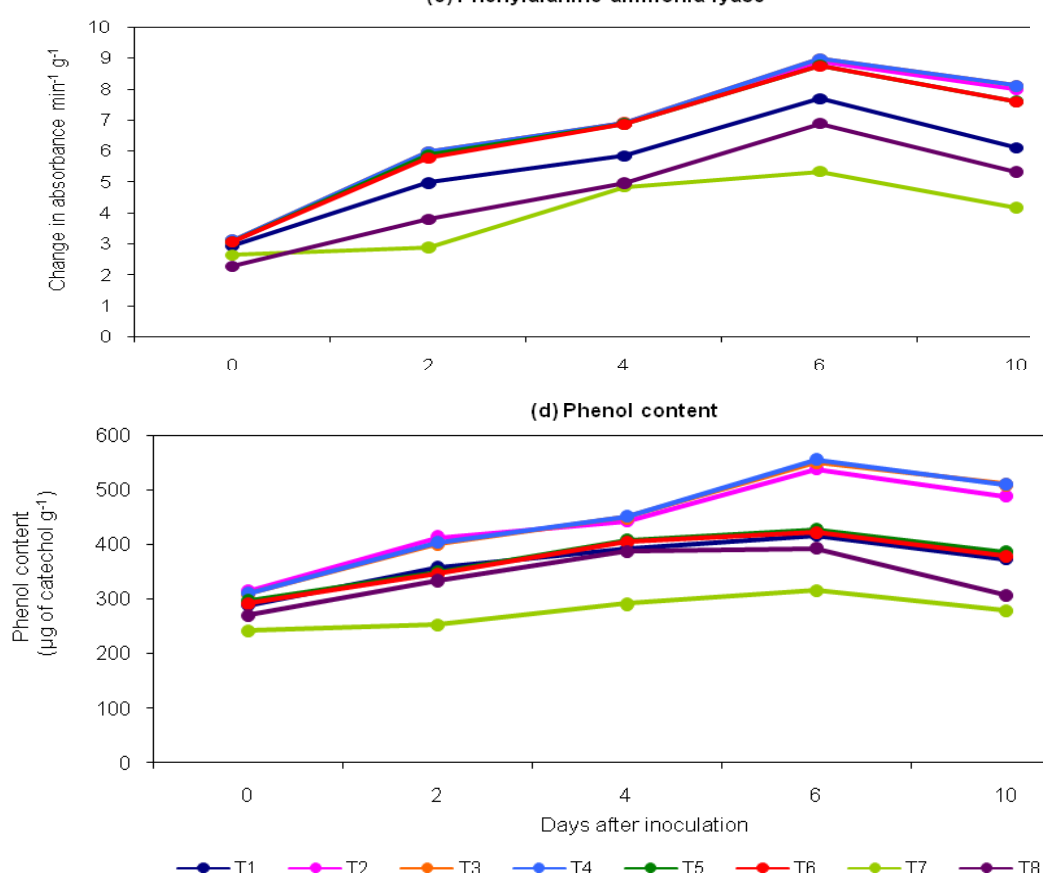

According to Ramanathan et al., (2000) the induction of defense proteins makes the plant resistant to pathogen invasion and the results of the present study revealed that the tomato plants applied with P-40 significantly induced the defense compounds (PO, PPO, PAL and 
phenol) compared to unsprayed control. The resistance of plants induced against the pathogens, due to the application of botanicals has been widely reported (Straub et al., 1986).

Spraying of P-40 enhanced the accumulation of defense enzymes and total phenol content on challenge inoculation with $F$. oxysporum f.sp. lycopersici in tomato which is in accordance with the results were reported by Rajeswari (2002) in grapes due to the application Wanis (a botanical formulation).

In conclusion, the "Polymin" exhibited high level of thermo and storage stability. On application it increased the germination percentage of tomato by reducing the seed infection by $F$. oxysporum f.sp. lycopersici. Under pot culture conditions, it potentially induced the resistance in tomato plants against $F$. oxysporum f.sp. lycopersici through enhancement of defense compounds (PO, PPO, PAL and phenol). With these findings, it is evident that the "Polymin" has the potential of controlling the incidence of $F$. oxysporum f.sp. lycopersici in tomato. In future, detailed study on the effect of Polymin on plant disease control under field conditions will provide an opportunity for crop disease management in an environmentally friendly manner.

\section{References}

Dongzhi, L., E. Tsuzuki, Y. Sugimoto, M. Yanjun Dong, M. Matsuo and $\mathrm{H}$. Terao. 2004. Allelopathic effects of aqueous Aloe vera leaf extracts on selected crops. Allelopat. J., 13: 6774.
Mayer, A.M., E. Harel and R.B. Sahul. 1965. Assay of catechol oxidase, a critical comparison of methods. Phytochem., 5: 783-789.

Mitchell, S.A and M. H. Ahmad. 2005. A review of medicinal plant research at the University of West Indies, Jamaica. West Indies Med. J., 55(4): 243-266.

ISTA, 1993. Proceedings of International Seed Test Association, International Rules for Seed Testing. Seed Sci. Technol., 21: 1152.

Puttur, J. 1974. Methods in Enzymatic Analysis. Bergmeyer (Ed.), Academic Press, New York. pp. 2-685.

Rajeswari, E. 2002. Biological control of major diseases of grape vine (Vitis vinifera L.). Ph. D Thesis, Tamil Nadu Agricultural University, Coimbatore, India. p. 220.

Ramanathan, A., R. Samiyappan and P. Vidyasekaran. 2000. Induction of defense mechanisms in green gram leaves and suspension cultured cells by Macrophomina phaseolina. J. Plant Dis. Prot., 107: 245-257.

Spies, J.R. 1955. Methods in Enzymology. III (Ed.) Colowick, S.P and W.D. Kalpan. Academic Press, pp. 467-468.

Straub, P., G. Adam and K.W. Mundry. 1986. Isolation and characterization of virus inhibitor from spinach (Spinaceae oleraceae L.). J. Phytopathol., 155: 357-367.

Zucker, M. 1965. Induction of PAL by light and its relation to chlorogenic acid and synthesis in potato tuber tissue. Plant Physiol., 40:779-784.

\section{How to cite this article:}

Parimala Devi, R. and Marimuthu, P. 2018. Controlling the Incidence of Fusarium oxysporum f.sp. lycopersici in Tomato by Application of the Newly Formulated Botanical Fungicide (Polymin 40 EC). Int.J.Curr.Microbiol.App.Sci. 7(07): 4191-4197.

doi: https://doi.org/10.20546/ijcmas.2018.707.489 